\title{
Evidence of two lineages of metriorhynchid crocodylomorphs in the Lower Cretaceous of the Czech Republic
}

\author{
Daniel Madzia, Sven Sachs, Mark T. Young, Alexander Lukeneder and Petr Skupien \\ Acta Palaeontologica Polonica 66 (2), 2021: 357-367 doi:https://doi.org/10.4202/app.00801.2020
}

Metriorhynchid crocodylomorphs were an important component in shallow marine ecosystems during the Middle Jurassic to Early Cretaceous in the European archipelago. While metriorhynchids are well known from western European countries, their central and eastern European record is poor and usually limited to isolated or fragmentary specimens which often hinders a precise taxonomic assignment. However, isolated elements such as tooth crowns, have been found to provide informative taxonomic identifications. Here we describe two isolated metriorhynchid tooth crowns from the upper Valanginian (Lower Cretaceous) of the Štramberk area, Czech Republic. Our assessment of the specimens, including multivariate analysis of dental measurements and surface enamel structures, indicates that the crowns belong to two distinct geosaurin taxa (Plesiosuchina? indet. and Torvoneustes? sp.) with different feeding adaptations. The specimens represent the first evidence of Metriorhynchidae from the Czech Republic and some of the youngest metriorhynchid specimens worldwide.

Key words: Crocodylomorpha, Thalattosuchia, Metriorhynchidae, Lower Cretaceous, Valanginian, Czech Republic.

Daniel Madzia [daniel.madzia@gmail.com, ORCID: https://orcid.org/0000-0003-1228-3573], Institute of Paleobiology, Polish Academy of Sciences, Twarda 51/55, 00-818 Warsaw, Poland. Sven Sachs [ㅁachs.Pal@gmail.com ], Naturkunde-Museum Bielefeld, Abteilung Geowissenschaften, Adenauerplatz 2, 33602 Bielefeld, Germany. Mark T. Young [mark.young@ed.ac.uk

, ORCID: https://orcid.org/0000-0002-7263-6505], School of GeoSciences, Grant Institute, University of Edinburgh, James Hutton Road, Edinburgh, EH9 3FE, UK. Alexander Lukeneder [alexander.lukeneder@nhm-wien.ac.at ], Natural History Museum Vienna, Geological and Palaeontological Department, Burgring 7, 1010 Vienna, Austria. Petr Skupien [petr.skupien@ vsb.cz], Department of Geological Engineering, VŠB - Technical University, 17. listopadu 15, 70833 Ostrava Poruba, Czech Republic. 
This is an open-access article distributed under the terms of the Creative Commons

Attribution License (for details please see creativecommons.org), which permits unrestricted use, distribution, and reproduction in any medium, provided the original author and source are credited.

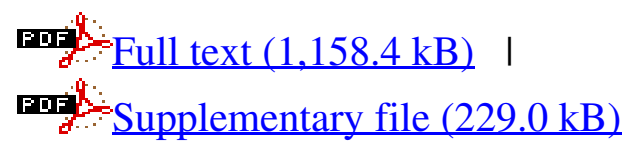

